Journal of Animal and Veterinary Advances 11 (13): 2289-2292, 2012

ISSN: $1680-5593$

(C) Medwell Journals, 2012

\title{
Expression of Fat2 mRNA in Canine Skin Tumors
}

\author{
${ }^{1,3}$ Seiya Matsui, ${ }^{2}$ Kazumi Sasai and ${ }^{1}$ Tadayoshi Takeuchi \\ ${ }^{1}$ Department of Veterinary Pharmacology, ${ }^{2}$ Department of Veterinary Internal Medicine, \\ Graduate School of Life and Environmental Sciences, \\ Osaka Prefecture University, 599-8531 Osaka, Japan \\ ${ }^{3}$ Department of Strategies and Licensing, Maruho Co., Ltd., 531-0071 Osaka, Japan
}

\begin{abstract}
Fat cadherins are huge proteins that contain 34 cadherin repeats. Recent studies showed that human Fat2 was expressed at squamous cell carcinoma and mammal fat cadherins related to tumor. It is possible to speculate that Fat2 relate skin tumors. Canine skin tumor is one of the most common diseases and some skin tumors like melanoma are devastating. Therefore, many kinds of investigation about skin tumor are necessary for a certain and prompt diagnosis and prediction. We investigated the expression of Fatl and Fat2 mRNA in canine skin biopsies by RT-PCR. Samples of skin tissue were obtained from five healthy dogs and skin tumors of nine dogs from private veterinary hospital (Kitasuma Animal Hospital and Matsuoka Animal Hospital). Fat2 mRNA was not expressed in normal canine skin. However, we found that canine Fat 2 mRNA was expressed in six of nine $(67 \%)$ canine skin tumors. On the other hand, canine Fatl mRNA was not detected in canine normal skin and skin tumors. These results indicate that Fat2 might relate to skin tumors in dogs. The further study of Fat2 in dog might be important for clarifying the mechanism of skin tumors and developing the treatment.
\end{abstract}

Key words: Cadherin, canine, Fat2, skin, skin tumor, Japan

\section{INTRODUCTION}

The Ca (2+)-dependent cell-cell adhesion molecules, termed cadherins are components of intercellular adhesive junctions of epithelial cells. Various human or canine cadherins are expressed in skin and play a crucial role in the formation and maintenance of epithelial barriers and are involved in skin diseases (Takeuchi et al., 2002; Yabuzoe et al., 2009).

Fat cadherins are huge proteins that contain 34 cadherin repeats and that form a distinct subfamily of the cadherin superfamily (Tanoue and Takeichi, 2004). Four kinds of Fat cadherin, Fat1-Fat 4 have been identified. Fat was identified as a tumor suppressor protein in Drosophila (Mahoney et al., 1991). It has been reported that Fat1 and Fat2 are expressed in squamous cell carcinoma (Tanoue and Takeichi, 2004; Matsui et al., 2007). In addition, some studies relating to tumor have been reported in mammal Fat cadherins (Qi et al., 2009).

Canine skin tumor is one of the most common diseases. Cutaneous neoplasms were diagnosed in $22.8 \%$ of dogs based on the retrospective study (Villamil et al., 2011). Lipoma, adenoma and mast cell tumor are the most common skin tumor types (Villamil et al., 2011) and some kinds of skin tumor like melanoma are devastating.
Therefore, diagnosis is crucial for their life. Many studies about diagnostic marker, especially about melanoma and mast cell tumor have been reported such as S-100 protein for melanoma (Sandusky et al., 1985) and c-kit protein for mast cell tumor (Passantino et al., 2008). However, there is no single diagnostic technique capable of differentiating a benign tumor from devastating neoplasms or predicting survival time. Therefore, a further investigation about skin tumor of dog is necessary for a certain and prompt diagnosis and prediction.

The purpose of this study was to analyze the expression of Fatl and Fat 2 mRNA in canine skin because human Fat2 expressed in skin is possible to speculate the relationship to skin tumors. We found for the first time interesting results that canine Fat2 mRNA expressed in only skin tumors but not in normal skin.

\section{MATERIALS AND METHODS}

Preparation of cDNA: Animals are housed in the laboratory research facility at Osaka Prefecture University and the proper management of animals are carried out under the principles and guidelines approved by Osaka Prefecture University. Mouse (C57/BL6) and rat (Wistar/ST rat) skin specimens were split from root of the

Corresponding Author: Tadayoshi Takeuchi, Department of Veterinary Pharmacology, Graduate School of Life and Environmental Sciences, Osaka Prefecture University, Izumisano, 599-8531 Osaka, Japan 
J. Anim. Vet. Adv., 11 (13): 2289-2292, 2012

Table 1: Characteristics of canine patients with skin tumors

\begin{tabular}{|c|c|c|c|c|c|c|c|}
\hline Breeds & Site & Diagnosis & Age & Sex & Acute/chronic & Benign/malignant & Prognosis \\
\hline Papillan & Anal & Papilloma & 11 & Neutered male & Acute & Unknown & No recurrence \\
\hline Mongrel & Chest & Hemangiopericytoma & 11 & Neutered female & Chronic & Malignant & Recurrence \\
\hline Sheltie & Cheek & Trichoblastoma & 10 & Neutered female & Acute & Benign & No recurrence \\
\hline Miniature dachshund & Labia oris & Papilloma & 12 & Neutered female & Acute & Unknown & No recurrence \\
\hline Shih Tzu & Chest & Lipoma & Unknown & Neutered male & Unknown & Benign & No recurrence \\
\hline Kishu-inu & Mandible & Epithelioma & 10 & Neutered female & Acute & Benign & No recurrence \\
\hline Miniature dachshund & Chest & Epithelioma & 6 & Neutered female & Acute & Unknown & No recurrence \\
\hline Mongrel & Mammary gland & Mammary gland adenocarcina & 12 & Neutered female & Chronic & Malignant & Unknown \\
\hline Shepherd & Ear & Trichoepithelioma & 8 & Female & Acute & Benign & Death \\
\hline
\end{tabular}

Table 2: Oligonucleotide primers for PCR

\begin{tabular}{|c|c|c|c|c|}
\hline Genes & Primer & Sequence & Size & Seaquence reference \\
\hline Mouse Fatl & $\begin{array}{l}\text { Forward } \\
\text { Reverse }\end{array}$ & $\begin{array}{l}5 \text { '-aacaaccttgaccgcaattc } \\
5 \text { '-tgtgtgttcgtcaatagcct }\end{array}$ & $471 \mathrm{bp}$ & NM_001081286 \\
\hline Mouse Fat 2 & $\begin{array}{l}\text { Forward } \\
\text { Reverse }\end{array}$ & $\begin{array}{l}\text { 5'-gcagtctggcctccaactta } \\
\text { 5'-atgctcacccccttatagcc }\end{array}$ & $365 \mathrm{bp}$ & NM_001029988.2 \\
\hline Mouse E-cadherin & $\begin{array}{l}\text { Forward } \\
\text { Reverse }\end{array}$ & $\begin{array}{l}5 \text { '-aacttggggacagcaacatc } \\
\text { 5'-gggagatctgactgcctctg }\end{array}$ & $324 \mathrm{bp}$ & NM_009864.2 \\
\hline Mouse $\beta$-actin & $\begin{array}{l}\text { Forward } \\
\text { Reverse }\end{array}$ & $\begin{array}{l}5 \text { '-gccaaccgcgagaagatgac } \\
\text { 5'-gaaggtagtttcgtggatgc }\end{array}$ & 487 bp & NM_009608.2 \\
\hline Rat Fotll & $\begin{array}{l}\text { Forward } \\
\text { Reverse }\end{array}$ & $\begin{array}{l}5 \text { '-agctgggacttcgactacga } \\
5 \text { '-actcgaactggtcgctgaat }\end{array}$ & $403 \mathrm{bp}$ & NM_031819.1 \\
\hline Rat Fot 2 & $\begin{array}{l}\text { Forward } \\
\text { Reverse }\end{array}$ & $\begin{array}{l}5 \text { '-gtctcagcagagctggacct } \\
5 \text { '-actggcagatctgagcgatt }\end{array}$ & $437 \mathrm{bp}$ & NM_022954 \\
\hline Rat E-cadherin & $\begin{array}{l}\text { Forward } \\
\text { Reverse }\end{array}$ & $\begin{array}{l}\text { 5'-caggattacaagttcccgcca } \\
\text { 5'-cactgtccgctgcttca }\end{array}$ & $354 \mathrm{bp}$ & NM_031334.1 \\
\hline Rat GAPDH & $\begin{array}{l}\text { Forward } \\
\text { Reverse }\end{array}$ & $\begin{array}{l}\text { 5'-ggcaagttcaatggcacagt } \\
\text { 5'-aagtggaggaatgggagt }\end{array}$ & $725 \mathrm{bp}$ & NM_017008.3 \\
\hline canine Fatl & $\begin{array}{l}\text { Forward } \\
\text { Reverse }\end{array}$ & $\begin{array}{l}5 \text { '-tctcgatcctgtctctcca } \\
5 \text { '-ggtgtatggactcgaactgt }\end{array}$ & $458 \mathrm{bp}$ & XM_532835.2 \\
\hline canine Fat 2 & $\begin{array}{l}\text { Forward } \\
\text { Reverse }\end{array}$ & $\begin{array}{l}\text { 5'-aaactatgcctgccatcgag } \\
\text { 5'-tcttccaggttctggttgct }\end{array}$ & $408 \mathrm{bp}$ & XM_536461.2 \\
\hline canine E-cadherin & $\begin{array}{l}\text { Forward } \\
\text { Reverse }\end{array}$ & $\begin{array}{l}5 \text { '-cgtcgaaatcgctgtactca } \\
\text { 5'-tggattaacctccagccaac }\end{array}$ & $442 b p$ & XM_536807.2 \\
\hline canine GAPDH & $\begin{array}{l}\text { Forward } \\
\text { Reverse }\end{array}$ & $\begin{array}{l}\text { 5'-atcactgccacccagaagac } \\
\text { 5'-aggccatgtagaccatgagg }\end{array}$ & $409 \mathrm{bp}$ & XM_845086 \\
\hline
\end{tabular}

tail using fine forceps and then incubated in $8 \mathrm{mg} \mathrm{mL}^{-1}$ dispase at $4^{\circ} \mathrm{C}$ overnight to allow separation of epidermis and dermis (Longley et al., 1991). Epidermal sheets were carefully peeled away from dermis. On the other hand, we could not obtain canine skin sample of enough quantity to separate its epidermis. Therefore canine skin biopsies were excised and immediately submerged in RNA stabilization solution, RNAlater (Ambion, Carlsbad, CA). The murine epidermal cell line Pam 212 was generously gifted from Dr. Stuart Yuspa, National Institutes of Health, Bethesda, MD. Total RNA was extracted using RNeasy Mini kit (QIAGEN, Valencia, CA) and first-strand cDNAs were generated using Omniscript RT kit (QIAGEN) with oligo dT primers (Invitrogen, Chiba, Japan).

Biopsies from skin tumors in dogs were obtained from private veterinary hospital between March 16, 2010 and November 9, 2010 based on owner's acceptance in writing. The biopsies were obtained by mastectomy or block dissection from nine dogs of different breeds (mean age 10 years). Animals had not received any treatment including chemotherapy and radiotherapy, prior to surgery. All specimens were immediately immersed in an
RNAlater solution and stored at $4^{\circ} \mathrm{C}$ until further processing. Histological analysis was performed to ensure that the tissues were either malignant or normal (Table 1).

RT-PCR: It was performed RT-PCR using specific primers for Fat1, Fat2, E-cadherin and GAPDH/ $\beta$-actin (Table 2). The PCR reaction with Taq Master Mix (QLAGEN) was proceeded as follows: denaturation at $94^{\circ} \mathrm{C}$ for $5 \mathrm{~min}, 30$ cycles of denaturation at $94^{\circ} \mathrm{C}$ for $1 \mathrm{~min}$, hybridization at $60^{\circ} \mathrm{C}$ for $1 \mathrm{~min}$, extension at $72^{\circ} \mathrm{C}$ for $1 \mathrm{~min}$ and final extension at $72^{\circ} \mathrm{C}$ for $5 \mathrm{~min}$. The PCR products were separated on $2 \%$ agarose gels and stained with ethidium bromide.

\section{RESULTS AND DISCUSSION}

At first, the expressions of Fat 2 mRNA in normal canine skin (normal female Collie, the same sample as N1), normal mouse epidermis, normal rat epidermis and the murine epidermal cell line Pam 212 were analyzed. The GAPDH and E-cadherin bands were detected as a control. As shown in Fig. 1, Fatl and Fat2 mRNA were not 


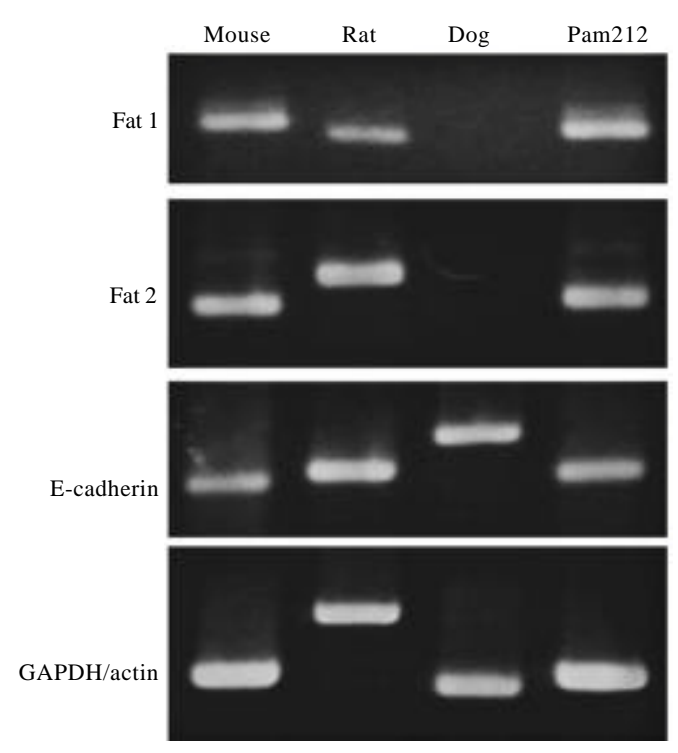

Fig. 1: mRNA expressions of various cadherin in normal skin. The mRNA expression of Fatl, Fat2, E-cadherin and GAPDH/ $\beta$-actin was examined by RT-PCR in canine skin, mouse epidermis, rat epidermis and Pam 212 cells using specific primers. The expression of GAPDH (rat and canine) and $\beta$-actin (mouse) was used as a loading control for the reactions and to ensure integrity of the RNA

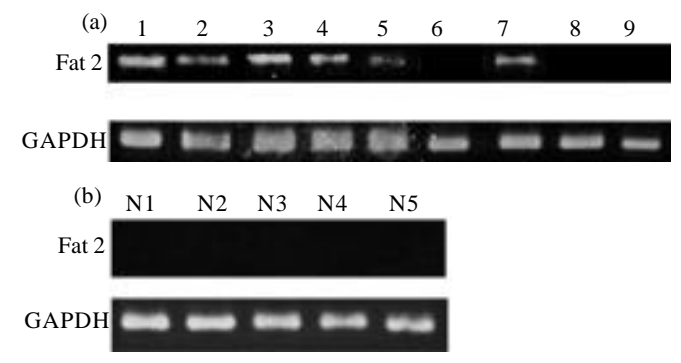

Fig. 2: mRNA expressions of Fat2 in canine skin tumors. The mRNA expression of Fat 2 and GAPDH was examined by RT-PCR in canine skin tumors using specific primers; a) Lane numbers indicate patient number in Table 2 and b) Lane number indicate as follows: N1 is normal female Collie, N2 is normal male Papillon, N3 is normal male Shih Tzu, N4 is normal female Miniature Dachshund and N5 is normal male Beagle

expressed in normal canine skin. Normal canine skin expressed E-cadherin which is essential cadherin for maintaining homeostasis in epidermis (Fig.1). As well as Fig. 1, other normal canine skins (Fig. 2; N2-N5) expressed E-cadherin mRNA and did not express Fatl. On the other hand, Fat1 and Fat2 mRNA were clearly expressed in mouse and rat epidermis and Pam 212 cells like human epidermis (Matsui et al., 2007) (Fig. 1). It has been already reported that Fat1 is expressed in mouse skin (Tanoue and Takeichi, 2005). We showed for the first time that mouse and rat epidermis expressed Fat 2 mRNA. Human Fat2 was expressed in Squamous Cell Carcinoma (SCC) in addition to normal skin (Matsui et al., 2007). Next, we further investigated the expression of Fat 2 mRNA in canine skin tissues. Samples of skin tissue were obtained from five healthy dogs and skin tumors of nine dogs (Table 1). Fat2 mRNA expression was restricted to the tumors being found in six (No.1-5 and 7) of nine (67\%) canine skin tumors but not in any normal canine skin (Fig. 2). We compared Fat 2 mRNA expression in the tumor lesion and the normal site in same dog which had skin tumor. Fat2 mRNA was not detected in normal skin in other dogs which have skin tumor. Fatl mRNA was not detected in skin tumors of all dogs which we examined.

According to various reports, about $30-45 \%$ of all canine tumors are known to occur in the skin and subcutaneous tissues (Muller et al., 1983). The incidence of skin tumors is known to be high at old dogs, female dogs and dogs of particular breeds (Muller et al., 1983). In the present study, Fat2 mRNA was expressed in skin tumors of some dogs but in not all one. It is reported previously that Fat is a tumor suppressor gene and knockdown of human Fat2 tended to promote epidermal cell proliferation (Matsui et al., 2008). These results indicate that the expression of Fat 2 in canine skin might relate to cell proliferation. Although, it is necessary to study the immunohistochemical detection of Fat 2 protein in canine normal skin and skin tumors using specific antibody, canine Fat2 antibody is unavailable in markets unfortunately. Furthermore, there are some tendencies for Fat2 mRNA to be expressed in skin tumors of old $\operatorname{dogs}$ ( 4 dogs is $>10$ years) (Table 1 ). There is no relationship between Fat2 expression and acuteness, malignancy and prognosis of canine skin tumors (Table 1). However, further studies of Fat2 are necessary to determine the relationship to them. Fatl mRNA was expressed in mouse epidermis, rat epidermis (Fig. 1) and human keratinocyte (Matsui et al., 2007) but was not detected in canine normal skin and skin tumors. This result suggests that Fat1 is not expressed in canine skin or the expression level of Fat1 is quite low and that the level of expression of Fatl in skin differs between animal spices.

\section{CONCLUSION}

In this study, it is suggest from the present study that Fat 2 might relate in any way to canine skin tumors 
such as cell proliferation. The further study of Fat 2 in dog might be important for clarifying the mechanism of skin tumors and developing the treatment.

\section{ACKNOWLEDGEMENTS}

Researchers thank the owners of the dogs and personnel of the veterinary clinics for their cooperation in Kitasuma Animal Hospital (Kobe City, Hyogo, Japan) and Matsuoka Animal Hospital (Hannan City, Osaka, Japan).

\section{REFERENCES}

Longley, J., T.G. Ding, C. Cuono, F. Durden and C. Crooks, et al., 1991. Isolation, detection and amplification of intact mRNA from dermatome strips, epidermal sheets and sorted epidermal cells. J. Invest. Dermatol., 97: 974-979.

Mahoney, P.A., U. Weber, P. Onofrechuk, H. Biessmann, P.J. Bryant and C.S. Goodman, 1991. The fat tumor suppressor gene in Drosophila encodes a novel member of the cadherin gene superfamily. Cell, 67: 853-868.

Matsui, S., A. Utani, K. Takahashi, Y. Mukoyama, Y. Miyachi and N. Matsuyoshi, 2007. Human Fat2 is localized at immature adherens junctions in epidermal keratinocytes. J. Dermatol. Sci., 48: 233-236.

Matsui, S., A. Utani, K. Takahashi, Y. Mukoyama, Y. Miyachi and N. Matsuyoshi, 2008. Knockdown of Fat 2 by siRNA inhibits the migration of human squamous carcinoma cells. J. Dermatol. Sci, 51: $207-210$.

Muller, G.H., R.W. Kirk and D.W. Scott, 1983. Small Animal Dermatology. 3rd Edn., W.B.Saunders Company, Philadelphia, ISBN-13: 9780721666099 , pp: 889 .
Passantino, L., G. Passantino, A. Cianciotta, M.R. Ribaud, G. Lo Presti, G. Ranieri and A. Perillo, 2008. Expression of proto-oncogene C-kit and correlation with morphological evaluations in canine cutaneous mast cell tumors. Immunopharmacol. Immunotoxicol., 30: 609-621.

Qi, C., Y.T. Zhu, L. Hu and Y.J. Zhu, 2009. Identification of Fat4 as a candidate tumor suppressor gene in breast cancers. Int. J. Cancer, 124: 793-798.

Sandusky, G.E., W.W. Carlton and K.A. Wightman, 1985. Immunohistochemical staining for S100 protein in the diagnosis of canine amelanotic melanoma. Vet. Pathol., 22: 577-581.

Takeuchi, T., S.B. Liang and Y. Ohtsuki, 2002. Downregulation of expression of a novel cadherin molecule, T-cadherin, in basal cell carcinoma of the skin. Mol. Carcinog., 35: 173-179.

Tanoue, T. and M. Takeichi, 2004. Mammalian Fatl cadherin regulates actin dynamics and cell-cell contact. J. Cell Biol., 165: 517-528.

Tanoue, T. and M. Takeichi, 2005. New insights into Fat cadherins. J. Cell Sci., 118: 2347-2353.

Villamil, J.A., C.J. Henry, J.N. Bryan, M. Ellersieck, L. Schultz, J.W. Tyler and A.W. Hahn, 2011. Identification of the most common cutaneous neoplasms in dogs and evaluation of breed and age distributions for selected neoplasms. J. Am. Vet. Med. Assoc., 239: 960-965.

Yabuzoe, A., A. Shimizu, K. Nishifuji, Y. Momoi, A. Ishiko and T. Iwasaki, 2009. Canine pemphigus foliaceus antigen is localized within desmosomes of keratinocyte. Vet. Immunol. Immunopathol., 127: 57-64. 